\title{
Karakteristik Perusahaan Terhadap Luas Pengungkapan Corporate Social Responsibility
}

\author{
Aryo Prakoso ${ }^{1 *}$, Aulia Ayu Dewinta ${ }^{2}$ \\ 1,2 Universitas Jember \\ 1aryo.fisip@unej.ac.id, ${ }^{2}$ aulia.dewinta@unej.ac.id \\ *Corresponding author
}

\begin{abstract}
Globalization provides open competition to every business actor, to become a superior and valuable company one of the ways that can be taken by the company through disclosure of the corporate social reports (CSR). This paper wants to explore how far the characteristics of the company influence the extent of CSR disclosure. The method in this study uses the empirical study hypothesis testing approach by sampling all companies indexed L-Q45 on the Indonesia stock exchange. The reason selection of this index is the leading index in Indonesia with tightly defined criteria by regulators, including levels of liquidity, market capitalization, and growth prospects of the company. The results of the data analysis that has been done obtained results Profitability and total assets influence the broad disclosure of CSR, this also supports stakeholder theory and legitimacy theory, on the contrary, leverage does not affect the broad disclosure of CSR. That caused by the management of the company seeing high leverage tends to reduce the disclosure of social responsibility so as not to be in the spotlight of the debtholders.
\end{abstract}

Keywords: company characteristics, profitability, total assets, leverage, CSR

\begin{abstract}
Abstrak
Globalisasi memberikan persaingan terbuka kepada setiap pelaku bisnis, untuk menjadi perusahaan yang unggul dan bernilai, salah satu cara yang dapat diambil oleh perusahaan melalui pengungkapan laporan sosial perusahaan (CSR). Makalah ini ingin mengeksplorasi sejauh mana karakteristik perusahaan mempengaruhi tingkat pengungkapan CSR. Metode dalam penelitian ini menggunakan pendekatan pengujian hipotesis studi empiris dengan pengambilan sampel semua perusahaan yang diindeks L-Q45 di bursa efek Indonesia. Alasan pemilihan indeks ini adalah indeks utama di Indonesia dengan kriteria yang ditetapkan oleh regulator, termasuk tingkat likuiditas, kapitalisasi pasar, dan prospek pertumbuhan perusahaan. Hasil analisis data yang telah dilakukan diperoleh hasil Profitabilitas dan total aset berpengaruh terhadap pengungkapan luas CSR, ini juga mendukung teori stakeholder dan teori legitimasi, sebaliknya, leverage tidak mempengaruhi pengungkapan luas CSR. Itu disebabkan oleh manajemen perusahaan melihat leverage yang tinggi cenderung mengurangi pengungkapan tanggung jawab sosial sehingga tidak menjadi sorotan para debtholders.
\end{abstract}

Kata kunci: karakteristik perusahaan, profitabilitas, total aset, leverage, CSR 


\section{PENDAHULUAN}

Lingkungan dan kualitas hidup masyarakat sangat berkaitan erat dengan aktivitas industry. Perusahaan hadir tidak hanya memperhatikan kebutuhan share holder, akan tetapi perlu juga memperhatikan keterlibatan stakeholder, baik internal maupun eksternal perusahaan. Jaminan keselamatan kerja karyawan serta mutu dan keamanan produk sering dikaitkan dengan perhatian yang kurang dari perusahaan terhadap kualitas hidup masyarakat. Perusahaan harus menyadari setiap langkah yang diambil akan memiliki konsekuensi terhadap lingkungan dan kualitas hidup masyarakat di sekitarnya (Overland, 2011). Point of view agency theory dengan mengulas tanggung jawab tataelola perusahaan untuk kepentingan pemegang saham menuju perspektif stakeholder theory melalui dorongan untuk mempertimbangkan aspek kepentingan hidup masyarakat luas. Fungsi manajemen perusahaan tidak hanya memaksimalkan laba, tetapi juga memperhatikan komitmen dalam hal pertanggung jawaban sosial dan lingkungan serta meningkatkan peranannya dalam pembangunan bangsa. Komitmen jamak disebut tanggungjawab sosial perusahaan (CSR). Tema CSR dan pengungkapannya dalam laporan tahunan akan menjadi garis besar pembahasan pada penelitian ini.

Nilai dan tingkat keberlangsungan hidup perusahaan tidak hanya digambarkan secara finansial saja tetapi juga dapat mengikuti pendekatan triple bottom lines yang dipandang secara holistik dari aspek sosial, lingkungan, dan keuangan (Rustiarini, 2010). Konsep tersebut mendorong perusahaan melakukan pengungkapan terhadap aspek social, ethical, enviromental, and sustainability (SEES) dalam laporan tahunan sebagai bentuk komunikasi informasi dan akuntabilitasnya kepada para stakeholder. Pemerintah sebagai regulator, sosialisasi dan implementasi program serta pengungkapan CSR di Indonesia melalui laporan tahunan sudah diakomodasi. Pemerintah Indonesia telah mengeluarkan kebijakan mengenai CSR yang diatur dalam UU No. 40 tahun 2007 tentang Perseroan Terbatas, UU No. 25 tahun 2007 tentang Penanaman Modal. Ikatan Akuntan Indonesia (IAI) dalam Pernyataan Standar Akuntansi Keuangan (PSAK) Nomor 1 paragraf 9 secara implisit menyarankan perusahaan untuk menggambarkan tanggung jawab sosial perusahaan dalam bentuk pelaporan masalah lingkungan social.

Bursa Efek Indonesia, sebagai wadah bertemunya perusahaan dan investor memberikan reverensi dan kapasitas bagaimana kinerja perusahaan yang terindeks di dalamnya. Salah satu indeks unggulan, adalah LQ-45, indeks ini merupakan indeks unggulan dengan keriteria unggulan yang ditetapkan oleh regulator, kriteria yang dipakai untuk masuk dalam indeks ini antaralain tingkat llikuiditas, kapitalisasi pasar, serta prospek pertumbuhan perusahaan tersebut. BEI secara berkala melihat perkembangan kinerja perusahaan indeks LQ45 setiap tiga bulan dan melakukan evaluasi. Penggantian saham akan dilakukan setiap enam bulan sekali, yaitu pada awal bulan Februari dan Agustus. Menarik untuk menggali Pengungkapan CSR indeks LQ-45 yang digambarkan sebagai ketersediaan informasi finansial dan nonfinansial terkait dengan interaksi organisasi dengan lingkungan fisik dan lingkungan sosialnya, yang dapat dibuat dalam laporan tahunan perusahaan atau laporan sosial terpisah (Sembiring, 2003).

Kompleksitas bisnis unik dan berbeda setiap perusahaan akan memberikan perbedaan dalam kompleksitas aktivitas CSR-nya, sehingga dapat diasumsikan bahwa perbedaan dalam 
aktivitas bisnis setiap perusahaan menjadi ciri-ciri atau karakteristik suatu perusahaan. Karakteristik perusahaan diasumsikan memiliki pengaruh terhadap luas pengungkapan laporan tahunan termasuk laporan CSR karena berkaitan dengan kompleksitas yang berbeda untuk setiap perusahaan dalam melaksanakan dan mengungkapkan kegiatan sosialnya.Karakteristik perusahaan dapat ditinjau antara lain dari size perusahaan, kemampuan menghasilkan laba, profile perusahaan, proporsi jumlah komisaris independen, dan leverage.

Coase et al (1937) menyebut bahwa hubungan agensi muncul ketika principal mempekerjakan orang lain (agent) untuk menjalankan dan pengambil keputusan perusahaan atas nama principal. Manajer (agent) yang diangkat oleh shareholder (principal) diharapkan akan bertindak untuk memaksimumkan profit perusahaan sehingga pencapaian target kemakmuran shareholder dapat diwujudkan. Agent dalam aktivitas operasional perusahaan sering bertindak atas kepentingan pribadi, bukan untuk kepentingan principal, tetapi bertindak untuk meningkatkan kesejahteraannya antara lain memperoleh investasi, dan pinjaman bank. Adapun Stakeholder theory dsebagaii dasar untuk menganalisa kelompok yang menjadi objek pertanggungjawaban perusahaan. Menurut Freeman (1984) dalam (Sumedi, 2010) stakeholder merupakan kelompok atau individu yang memiliki perngaruh goals tujuan organisasi. Lebih lanjut dalam Legitimacy Theory

Teori ini fokus pada interaksi perusahaan dan masyarakat. Lindblom (1994) dalam Yuliana, Purnomosidhi, \& Sukoharsono, (2008) menyatakan inti dari legitimacy theory adalah suatu kondisi ketika sistem nilai suatu entitas sesuai dengan sistem nilai dari sistem sosial yang lebih besar dan merupakan bagian dari entitas tersebut. Perselisihan kedua sistem nilai dapat mengakibatkan adanya resiko pada legitimasi entitas perusahaan. CSR muncul sebagai salah satu mediator yang dapat digunakan perusahaan dan stakeholder serta menjadi pembuka jalan untuk memperoleh keuntungan, reaksi positif dari lingkungan, dan mendapatkan legitimasi atas usaha perusahaan.

Selanjutnya dalam Signalling theory memiliki inti pentingnya informasi yang dikeluarkan perusahaan atas keputusan investasi bagipihak diluar perusahaan. Informasi merupakan unsur penting bagi investor dan pelaku bisnis, karena pada dasarnya memberikan gambaran perusahaan baik untuk keadaan masa lalu, saat ini, maupun keadaan masa yang akan datang bagi kelangsungan hidup suatu perusahaan.

Karakteristik suatu perusahaan dapat dilihat pada isi atau data akuntansi dari laporan keuangan. Klasifikasi karakteristik perusahaan menjadi tiga kategori berdasarkan konteks pelaporan keuangan, yaitu: (1) Karakteristik perusahaan terkait dengan struktur perusahaan; (2) Karakteristik perusahaan terkait dengan kinerja perusahaan; (3) Karakteristik perusahaan terkait dengan pasar.

Studi terdahulu mengenai tentang karakteristik perusahaan terhadap luas pengungkapan CSR menunjukkan hasil yang beragam. Adhi (2012) yang menunjukkan bahwa ukuran perusahaan memiliki pengaruh terhadap luas pengungkapan CSR, sebaliknya rasio leverage, rasio likuiditas, dan basis perusahaan ditemukan tidak berpengaruh terhadap pengungkapan CSR. Penelitian Hasibuan (2001) menunjukkan bahwa hanya ukuran dan profile perusahaan yang berpengaruh terhadap praktik pengungkapan CSR. Sebaliknya, profitabilitas dan leverage tidak berpengaruh. Penelitian Kasmadi \& Susanto (2004) memiliki hasil basis perusahaan dan rasio leverage berpengaruh terhadap luas pengungkapan CSR. Sebaliknya, ukuran, 
tingkat return, dan tipe industri tidak berpengaruh terhadap luas pengungkapan CSR. Reni dan Anggraini, (2006) memperoleh persentase kepemilikan manajemen dan tipe industri yang terbukti memiliki pengaruh terhadap pengungkapan CSR, sebaliknya profitabilitas dan ukuran perusahaan tidak berpengaruh terhadap pengungkapan CSR.

\section{METODE}

Penelitian ini merupakan penelitian kuantitatif dengan pendekatan hypothesis testing empirical study, yaitu metode yang digunakan untuk mengetahui konsistensi hasil temuan empiris, terutama yang berkaitan dengan pengaruh variabel independen terhadap variabel dependen (Sekaran, 2009)

Populasi dalam penelitian ini adalah seluruh perusahaan yang terindeks LQ-45 Bursa Efek Indonesia periode 2017. Alasan dipilihnya periode waktu tersebut adalah karena laporan tahunan 2017 baik keuangan maupun laporan CSR tiap perusahaan relatif baru, dapat diperoleh di website BEI dan Indonesian Capital Market Directory (ICMD). Adapun sample ditentukanmenggunakan non-probability sampling, dengan metode judgment sampling, yaitu Teknik pemilihan sampel yang dilakukan sesuai dengan kriteria tertentu yang akan diamati (Sekaran, 2009). Kriteria yang diambil antara lain: (a) Sampel penelitian merupakan perusahaan telah terdaftar indeks dalam LQ-45 Periode 2017; (b) Menyajikan laporan keberlanjutan CSR d per 31 Desember 2017; (c) Perusahaan memiliki data yang lengkap pada ICMD terkait dengan variabel-variabel yang digunakan dalam penelitian.

Sumber data dalam penelitian ini adalah sumber data sekunder. Data sekunder merupakan sumber data penelitian yang diperoleh secara tidak langsung. Data sekunder umumnya berupa bukti, catatan atau laporan historis yang telah disusun dalam arsip (data dokumenter) yang dipublikasikan dan yang tidak dipublikasikan (Indriantoro, N dan Supomo $B, 2002)$. Data yang digunakan diperoleh melalui website IDX, website perusahaan serta ICMD.

Teknik analisis yang dipergunakan dalam penelitian ini ialah regresi berganda. Adapun persamaan matematis yang diajukan ialah:

$$
\operatorname{CSR}=\alpha+\beta 1 \text { SIZE }+\beta 2 \text { ROA }+\beta 3 \text { LEV }+\varepsilon
$$

Keterangan:

SIZE : Ukuran perusahaan

ROA : Profitabilitas

LEV : Leverage

CSR : Luas pengungkapan CSR

\section{HASIL DAN PEMBAHASAN}

Uji normalitas menguji apakah dalam model regresi, variabel independen dan variabel dependen, keduanya terdistribusi secara normal atau tidak. Berdasarkan uji pengolahan data (Gambar 1), diperoleh hasil grafik dengan titik- titik mendekati dan konsisten searah dengan garis diagonal. Hal ini menunjukkan semua data terdistribusi secara normal dan tidak terjadi penyimpangan, sehingga data yang dikumpulkan dapat diproses dengan metodemetode selanjutnya. 
Uji ini digunakan untuk melihat apakah model terjadi multikolinearitas diantara sesama variabel bebas. Penilaian menggunakan VIF (Variance Inflation Factor). Jika nilai toleransi di bawah 0,1 dan VIF lebih besar dari 10 maka terjadi hubungan linear yang sempurna di antara sesama variabel bebas sehingga dapat dikatakan terjadi multikolinearitas.

Gambar 1 P-P Plot

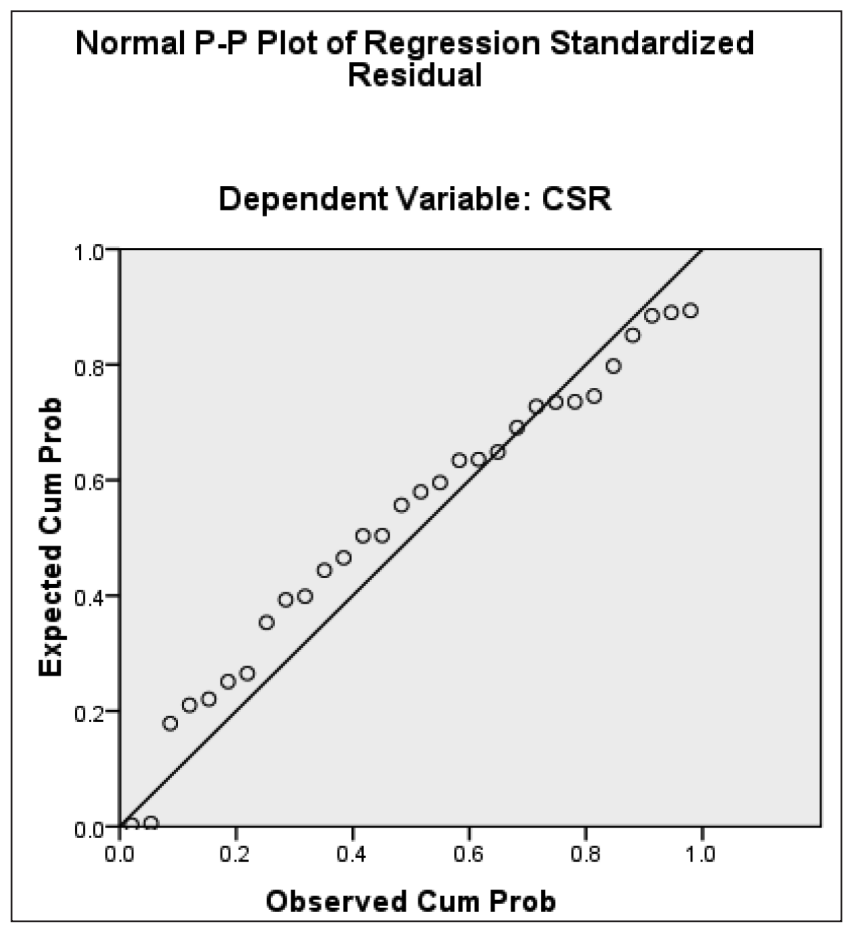

Sumber : Output SPSS data diolah, 2019

Hasil Tabel 2 menunjukkan bahwa variabel ROA, Leverage, dan Ln Asset diperoleh nilai VIF diatas 0,1 dan $\mathrm{n}$ di bawah 10, disimpulkan bahwa tidak terdapat hubungan linear antara variabel bebas atau tidak terjadi multikolinearitas pada setiap variabel.

Tabel 2. Hasil Uji Multikolinearitas

\begin{tabular}{lll}
\hline & VIF \\
\hline 1 & (Constant) & \\
& ROA & 1.747 \\
& Leverage & 1.033 \\
& Ln_Aset & 1.703 \\
\hline
\end{tabular}

Sumber : data diolah, 2019

Uji heteroskedastisitas yaitu pengujian terhadap adanya gangguan varians yang tidak sama. Untuk mendiagnosis adanya heteroskedastisitas yaitu dengan melihat grafik Scatterplot. 
Gambar 2 Hasil Analisis Grafik Uji Heteroskedastisitas

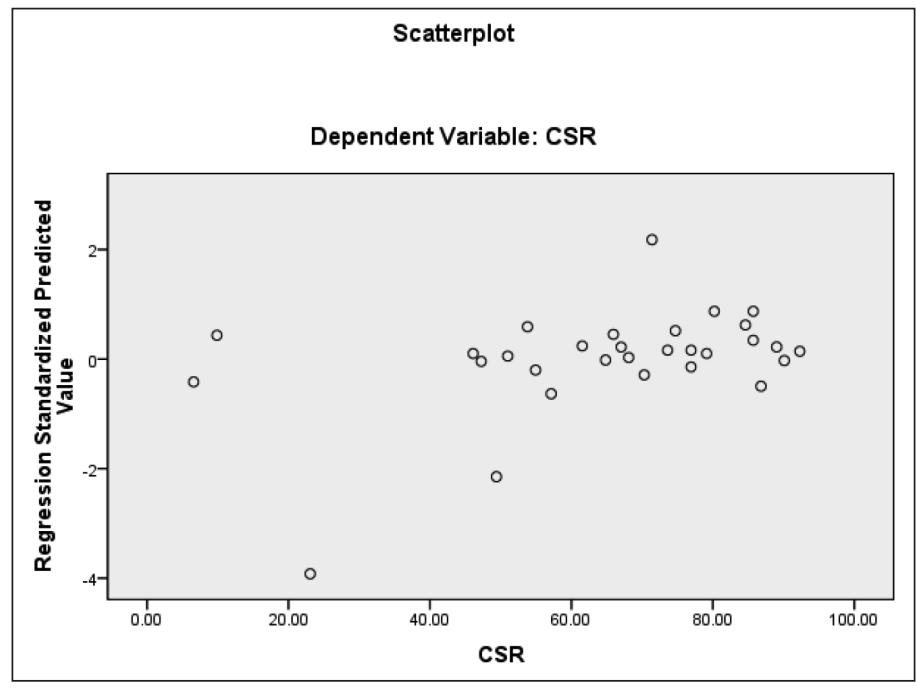

Sumber : data diolah, 2019

Gambar 2 menunjukkan bahwa tidak terjadi pembentukan pola yang jelas, serta titiktitik menyebar di atas dan di bawah angka 0 pada sumbu Y, sehingga dapat disimpulkan tidak terjadi heteroskedastisitas.

Selanjutnya, kita akan melakukan pengujian regresi. Hasil output SPSS untuk melihat persamaan regresi diperoleh pada Tabel 3.

Tabel 3. Hasil Regresi

\begin{tabular}{ccccccc}
\hline & \multicolumn{7}{c}{$\begin{array}{c}\text { Unstandardized } \\
\text { Coefficients }\end{array}$} & \multicolumn{2}{c}{$\begin{array}{c}\text { Standardized } \\
\text { Coefficients }\end{array}$} & & \\
Model & B & Std. Error & Beta & t & Sig. \\
\hline \multirow{2}{*}{1} & (Constant) & 15.209 & 39.384 & & .386 & .703 \\
& ROA & .206 & .594 & .082 & .347 & .032 \\
& Leverage & -1.063 & .629 & -.307 & -1.690 & .103 \\
& Ln_Aset & .037 & .036 & .178 & 1.043 & .030 \\
\hline
\end{tabular}

Sumber: Hasil Olahan Data

Dengan melihat tabel diatas diperoleh persamaan regresi sebagai berkut:

$\mathrm{Y}=15,209+0,206 \mathrm{ROA}-1,063$ leverage + 0,037 Ln_asset

Persamaan diatas dapat dijelaskan Konstanta (a) 15,209 menunjukkan bahwa apabila nilai variabel ROA, Leverage dan asset sebesar 0\% maka nilai rasio CSR sebesar 15,2\%.

Hasil pengolahan data, variabel ROA berpengaruh signifikan terhadap CSR. Kemudian, variabel Leverage tidak berpengaruh secara signifikan terhadap luas Pengungkapan CSR. Terakhir, variabel ukuran perusahaan berpengaruh secara signifikan terhadap luas pengungkapan CSR.

Besarnya nilai koefisien determinasi $\left(\mathrm{R}^{2}\right)$ menunjukkan tingkat pengaruh variabel independen terhadap dependen. Nilai Adjusted R Square sebesar 0,075. Hal ini menunjukkan bahwa 7,5\% perubahan yang terjadi pada pengungkapan CSR dari variabel bebas ROA, 
Leverage dan total aset dijelaskan oleh variabel tersebut, sebaliknya 92,5\% dijelaskan oleh variable lainnya yang tidak dibahas pada penelitian ini.

Tabel 4. Koefisien Determinasi

\begin{tabular}{cccc}
\hline Model & $\mathbf{R}$ & R Square & Adjusted R Square \\
\hline 1 & $.413^{\mathrm{a}}$ & .171 & .075 \\
\hline Sumber: Output SPSS, data diolah &
\end{tabular}

Hipotesis $\mathrm{H}_{1}$ profitabilitas berpengaruh terhadap luas pengungkapan CSR. Berdasarkan hasil uji t, dengan nilai sig 0,032, disimpulkan $\mathrm{H}_{1}$ bahwa profitabilitas berpengaruh terhadap luas pengungkapan CSR. Selaras dengan penelitian Sembiring (2003) dan Hossain et al., (2006) hasilnya tingkat profitabilitas berpengaruh terhadap pengungkapan CSR. Temuan ini mendukung stakeholder theory yang menunjukkan bahwa perusahaan yang memiliki tingkat profitabilitas tinggi akan mengungkapkan lebih banyak informasi mengenai kegiatan CSR yang telah dilakukan. Hal ini mungkin dikarenakan persepsi bahwa aktivitas CSR merupakan aktivitas yang bermanfaat bagi keberlangsungan perusahaan dan sebagai langkah strategis jangka panjang yang akan memberikan efek positif bagi perusahaan. Perusahaan dengan tingkat profitabilitas yang lebih tinggi akan memberikan fleksibilitas kepada manajemen untuk melaksanakan dan mengungkapkan CSR karena tidak ada hambatan dalam hal biaya pengungkapan. Belkaoui dan Karnik (1989) mengungkapkan manajemen yang sadar dan memperhatikan masalah sosial akan mengajukan pengungkapan yang diperlukan mengenai kemampuan perusahaan untuk menggerakkan kinerja keuangan perusahaan

Hipotesis $\mathrm{H}_{2}$ leverage berpengaruh terhadap luas pengungkapan CSR. Berdasarkan hasil uji t, nilai sig. sebesar 0,103, disimpulkan bahwa data penelitian tidak mendukung hipotesis $\mathrm{H}_{2}$ bahwa leverage secara langsung berpengaruh terhadap luas pengungkapan CSR. Hasil ini didukung Belkaoui dan Karnik (1989), Sembiring (2003), Noegrahen, (2005), dan Afni (2008) yang menunjukkan bahwa leverage tidak berpengaruh terhadap pengungkapan CSR perusahaan. Hasil ini tidak mendukung agency theory yang menyatakan bahwa leverage memiliki pengaruh terhadap pengungkapan CSR dan manajemen perusahaan dengan tingkat leverage yang cenderung tinggi akan mengurangi pengungkapan CSR yang dibuat agar tidak menjadi sorotan para debtholder. Kondisi ini dapat dijelaskan bahwa pada dasarnya kewajiban yang terdapat pada perusahaan merupakan kesepakatan antara pihak kreditor dengan pihak perusahaan. Apabila ditinjau lebih lanjut, kreditor dalam memberikan kredit atau pinjamannya akan mempertimbangkan beberapa factor seperti karakter, kemampuan untuk meminjam, kemampuan untuk menghasilkan pendapatan, modal, adanya jaminan dan kondisi ekonomi.

Oleh sebab itu, pengungkapan sukarela pada laporan tahunan, dalam hal ini pengungkapan CSR yang dilakukan oleh perusahaan tidak terkait dengan besar kecilnya tingkat solvabilitas perusahaan. Argumen lain yang dapat menjelaskan tidak adanya pengaruh dari tingkat leverage terhadap luas pengungkapan CSR dalam laporan tahunan adalah pada dasarnya rasio-rasio keuangan seperti tingkat leverage hanya mengukur kinerja keuangan perusahaan saja, sedangkan luas pengungkapan informasi dalam laporan tahunan berkaitan 
dengan kesadaran dan etika bisnis serta sebagai bagian dari transparansi dalam penerapan good corporate governance.

Hipotesis $\mathrm{H}_{3}$ ukuran perusahaan berpengaruh terhadap luas pengungkapan CSR. Berdasarkan hasil uji t, nilai sig 0,030 disimpulkan menerima hipotesis $\mathrm{H}_{3}$ bahwa ukuran perusahaan secara langsung berpengaruh terhadap luas pengungkapan CSR. Hasil ini konsisten dengan penelitian Belkaoui dan Karnik (1989), Hackston dan Milne (1996), Suripto (1999), Hasibuan (2001), Sembiring (2003), Afni (2008), dan Novita dan Djakman (2008) yang menghasilkan temuan bahwa ukuran perusahaan memiliki pengaruh terhadap pengungkapan CSR. Hasil dari penelitian ini mendukung legitimacy theory dan stakeholder theory bahwa perusahaan dengan ukuran besar memberikan perhatian yang lebih besar terhadap masyarakat dan stakeholder lainnya dalam hal pengungkapan sebagai alat komunikasi yang efisien dan perusahaan mendapat legitimasi dari masyarakat.

\section{SIMPULAN}

Hasil analisis data yang telah dilakukan, diperoleh hasil Profitabilitas dan total asset berpengaruh terhadap luas pengungkapan CSR sekaligus mendukung stakeholder theory dan legitimacy theory, sebaliknya, leverage tidak berpengaruh terhadap luas pengungkapan CSR. Untuk penelitian lebih lanjut, Penelitian ini hanya mendasarkan pada perusahaan yang terindeks di LQ 45 tahun 2017 Untuk itu disarankan bagi peneliti selanjutnya agar dapat melakukan penelitian yang lebih sempurna antaralain dengan menambah variabel yang digunakan,, periode dan objek yang diteliti.

\section{PUSTAKA ACUAN}

Adhi, N. (2012). Pengaruh Karakteristik Perusahaan Terhadap Luas Pengungkapan Sukarela dan Implikasinya Terhadap Asimetri Informasi. Skripsi. Universitas Diponegoro.

Afni, A. N. U. R. (2008). Praktek Social Dislosure dan Kaitannya dengan Karakteristik Perusahaan (Studi Empiris Pada Perusahaan yang Tercatat di Bursa Efek Indonesia). Universitas Sebelas Maret.

Belkaoui, A., \& Karnik, P. G. (1989). Determinants of the Corporate Decision to Disclose Social Information. Accounting, Auditing \& Accountability Journal, 2, 36-51. https:// doi.org/10.1108/09513578910132240

Cahyono, A. T. (2010). Reaksi Pasar atas Environmental Disclosures dan Karakteristik Perusahaan yang Mempengaruhinya. Universitas Brawijaya Malang.

Coase, R., Jensen, M. C., Meckling, W. H., Kim, J., Mahoney, J. T., \& Pandian, J. R. (1937). The Resource-Based View Within the Conversation of Strategic Management. Strategic Management Journal, 13(4), 223-242.

Darwis, H. (2009). Ukuran Perusahaan, Profitabilitas, dan Financial Leverage terhadap Pengungkapan Tanggung Jawab Sosial Perusahaan High Profile di BEI. Neliti.Com, 13(1), 52-61.

Galuh, R. (2011). Faktor-Faktor yang mempengaruhi Pengungkapan Sosial dalam Laporan Tahunan Perusahaan. Jurnal Online FE UNDIP, 1-24. 
Hackston, D., \& Milne, M. J. (1996). Some Determinants of Social and Environmental Disclosures in New Zealand Companies. Accounting, Auditing, and Accountability Journal, 9(1).

Hasibuan, muhammad rizal. (2001). Pengaruh Karakteristik Perusahaan terhadap Pengungkapan Sosial. Universitas Diponegoro.Semarang

hossain. M; islam.K; Andrew. J. (2006). Corporate Social and Environmental Disclosure in Developing Countries: Evidence from Bangladesh. The Asian Pacific Conference on International Accounting Issues.

Indriantoro Nur; Supomo B. (2002). Metodologi Penelitian Bisnis, Edisi Pertama. Yogyakarta: BPFE. Kasmadi, \& Susanto, D. (2004). Analisis Faktor-Faktor yang Mempengaruhi Luas Pengungkapan Sukarela dalam Laporan Tahunan Perusahaan- Perusahaan di Indonesia. Jurnal Akuntansi dan Manajemen.

Na'im, A., \& Rakhman, F. (2000). Analisis Hubungan Antara Kelengkapan Pengungkapan Laporan Keuangan Dengan Struktur Modal Dan Tipe Kepemilikan Perusahaan. Jurnal Ekonomi Dan Bisnis Indonesia, XV.

Noegraheni. (2005). Pegaruh Karakteristik Perusahaan terhadap Kualitas Pengungkapan Sukarela dalam laporan Tahunan pada Perusahaan Publik Non-Industri Keuangan di Bursa Efek Jakarta. EQUITY, 2(1).

Novita, \& Djakman, C. D. (2008). Pengaruh struktur kepemilikan terhadap luas pengungkap tanggung jawab sosial (CSR Disclosure) pada laporan tahunan perusahaan: Studi empiris pada perusahaan publik yang tercatat di Bursa Efek Indonesia pada tahun 2006. Simposium Nasional Akuntansi XI.

Overland, J. (2011). Corporate Social Responsibility in Context: The Case for Compulsory Sustainability Disclosure for Listed Public Companies in Australia? SSRN Electronic Journal. https://doi.org/10.2139/ssrn.1016606

Reni, F., \& Anggraini, R. (2006). Pengungkapan Informasi Sosial dan Faktor-Faktor yang Mempengaruhi Pengungkapan Informasi Sosial dalam Laporan Keuangan Tahunan (Studi Empiris pada Perusahaan-Perusahaan yang terdaftar Bursa Efek Jakarta ). Simposium Nasional Akuntansi 9 Padang, 23-26.

Rustiarini, N. W. (2010). Pengaruh Corporate Governance pada Hubungan Corporate Social Responsibility dan Nilai Perusahaan. Simposium Nasional Akuntansi XIII, (11), 1-24.

Sembiring, eddy rismanda. (2003). Kinerja Keuangan, Political Visibility, Ketergantungan pada Hutang, dan Pengungkapan Tanggung Jawab Sosial Perusahaan. Universitas Diponegoro. Semarang.

Setiawati, E., \& Artha, R. (2013). Pengaruh Karakteristik Perusahaan Terhadap CSR (Survey pada Industri Perbankan di Indonesia). Proceeding Seminar Nasional Dan Call for Papers Sancall 2013, 168-188.

Sumedi, A. M. P. (2010). Pengaruh Karakteristik Perusahaan dan Regulasi Pemerintah Terhadap Pengungkapan Corporate Social Responsibility (CSR) Pada Laporan Tahunan Di Indonesia. Universitas Diponegoro.Semarang

Suripto, B. (1999). Pengaruh Karakteristik Perusahaan terhadap Luas Pengungkapan Sukarela dalam Laporan Tahunan. Simposium Nasional Akuntansi II IAI-KAPd. 
Uma, S. (2009). Research Methods for Business: A Skill Building Approach (Fifth Edit). United Kingdom: John Wiley and Sons.

Yuliana, R. (2010). Jurnal Investasi Praktik Pengungkapan Corporate Social Responsibility (CSR) Di Indonesia (Studi pada Perusahaan yang Terdaftar di BEI). Jurnal Investasi, 6(2), 140-151.

Yuliana, R., Purnomosidhi, B., \& Sukoharsono, E. G. (2008). Pengaruh Karakteristik Perusahaan Terhadap Pengungkapan Corporate Social Responsibility (Csr) Dan Dampaknya Terhadap Reaksi Investor. Jurnal Akuntansi Dan Keuangan Indonesia, 5(2), 245-276. https://doi. org/10.21002/jaki.2008.12

Yuliani, R. (2003). Pengaruh Karakteristik Perusahaan terhadap Praktek Pengungkapan Sosial dan Lingkungan di Indonesia. Universitas Diponegoro. Semarang 